This is an electronic reprint of the original article. This reprint may differ from the original in pagination and typographic detail.

Author(s): Aunola, Kaisa; Nurmi, Jari-Erik; Lerkkanen, Marja-Kristiina; Rasku-Puttonen, Helena

Title: $\quad$ The roles of achievement-related behaviours and parental beliefs in children's mathematical performance

Year: $\quad 2003$

Version:

Please cite the original version:

Aunola, K., Nurmi, J.-E., Lerkkanen, M.-K., \& Rasku-Puttonen, H. (2003). The roles of achievement-related behaviours and parental beliefs in children's mathematical performance. Educational Psychology, 23(4), 403-421.

https://doi.org/10.1080/01443410303212

All material supplied via JYX is protected by copyright and other intellectual property rights, and duplication or sale of all or part of any of the repository collections is not permitted, except that material may be duplicated by you for your research use or educational purposes in electronic or print form. You must obtain permission for any other use. Electronic or print copies may not be offered, whether for sale or otherwise to anyone who is not an authorised user. 


\title{
The Role of Achievement-Related Behaviors and Parental Beliefs in Children's Mathematical Performance
}

\author{
Kaisa Aunola, Jari-Erik Nurmi, \\ Marja-Kristiina Lerkkanen and Helena Rasku-Puttonen \\ University of Jyväskylä, Finland
}

This study aimed at investigating the developmental dynamics between children's mathematical performance, the task-focused versus task-avoidant behaviors they show in the classroom, and their parents' beliefs concerning their offsprings' school competence. To investigate this, the mathematical performance of 111 six-to-seven-year-old children was tested, and their task-focused versus task-avoidant behaviors were rated by their teachers four times during their first school year. Parents filled in questionnaires measuring their skill-specific and general beliefs about their children's school competencies at the beginning and at the end of the school year. The results showed that parents' beliefs in their children's general school competence increased their children's task-focused behaviors at school, which further predicted the child's high level of math performance. Parents' beliefs in their children's competence in mathematics, in turn, contributed directly to the children's high mathematical performance. Moreover, children's high performance increased parents' subsequent beliefs in their children's mathematical competence, whereas children's taskfocused behaviors predicted parents' beliefs in their children's overall school performance.

Children's mathematical performance has been shown to be sensitive to various motivational, cognitive, and affective influences (Pajares \& Miller, 1994; Wigfield \& Meece, 1988), and the ways in which such factors are reflected in the behavior they show in the classroom (Onatsu-Arvilommi \& Nurmi, 2000). Further, parental beliefs have been found to be associated with both children's mathematical performance (Entwisle \& Alexander, 1990; Entwisle \& Baker, 1983; Galper, Wigfield, \& Seefeldt, 1997; Hess, Holloway, Dickson, \& Price, 1984; Huntsinger, Jose, Liaw, \& Ching, 1997; Jacobs, 1991), and also their achievement-related beliefs and motivation (Frome \& Eccles, 1998; Parsons, Adler, \& Kaczala, 1982; Stevenson \& Newman, 1986). This study focused on examining the developmental dynamics between children's achievement-related behaviors, their mathematical performance, and their mothers' and fathers' parental beliefs during the first year of primary school.

Children's achievement-related beliefs and behaviors have been shown to play an important role in their academic performance. Children who show a positive self-concept of ability (Chapman \& Tunmer, 1997; Mujis, 1997), expect success (Chapman, 1988), seek challenges (Dweck, 1990; Dweck \& Leggett, 1988), deploy task-focused behaviors (Onatsu-Arvilommi \& Nurmi, 2000; Skaalvik, 1997), and are persistent in the face of obstacles (Dweck, 1986; Mantzicopoulos, 1990; Rijavec \& Brdar, 1997) do well at school. By contrast, those who are afraid of failure, avoid challenges and are not persistent in learning situations show low- 
achievement (Butkowsky \& Willows, 1980; Carr, Borkowski, \& Maxwell, 1991; Diener \& Dweck, 1978; Nolen-Hoeksema, Girgus, \& Seligman, 1992; Nurmi, Onatsu, \& Haavisto, 1995; Midgley \& Urdan, 1995; Zuckerman, Kieffer, \& Knee, 1998) and even learning disabilities (Butkowsky \& Willows, 1980; Chapman, 1988). Although a variety of motivational styles and achievement strategies have been described previously (Diener \& Dweck, 1978; Dweck, 1986; Jones \& Berglas, 1978; Nicholls, Cheung, Lauer, \& Patashnick, 1989; Onatsu-Arvilommi \& Nurmi, 2000; Skaalvik, 1997), they seem to fall into two major categories. Task-focused strategies, such as mastery-orientation (Diener \& Dweck, 1978), task-involved goal orientation (Nicholls et al., 1989) and action-oriented coping strategies (Mantzicopoulos, 1990), are typically characterized by success expectations, high effort and persistence. Task-avoidant strategies, like learned helplessness (Diener \& Dweck, 1978), self-handicapping (Jones \& Berglas, 1978) and ego-oriented coping (Salonen, Lepola, \& Niemi, 1998) are typified by failure expectations, and low levels of effort and persistence in academic tasks. In the present study, such achievement-related patterns were operationalized in terms of task-focused versus task-avoidant behaviors.

A substantial amount of research has been carried out on the motivational and affective basis of children's mathematical performance: their performance has been associated with self-concept of math ability (Campbell \& Beaudry, 1998; Jacobs, 1991; Marsh, Walker, \& Debus, 1991; Pajares \& Miller, 1994), math selfefficacy (Pajares \& Graham, 1999; Pajares \& Kranzler, 1995), expectancies for future success (Alexander \& Entwisle, 1988; Jacobs, 1991), math anxiety (Pajares, \& Miller, 1994; Wigfield \& Meece, 1988), perceived difficulty (Frome \& Eccles, 1998), perceptions of math usefulness (Armstrong, 1985), and the motivation to avoid failure (Cock \& Halvari, 1999). However, this research has at least three major limitations. First, most of the studies have been cross-sectional (Ashcraft, Kirk, \& Hopko, 1998; Pajares \& Miller, 1994, for a review). Consequently, little is known about the developmental dynamics between children's achievement beliefs and behaviors, and their mathematical performance. Second, previous research has focused on children's achievement beliefs (Jacobs, 1991; Marsh et al., 1991; Pajares \& Kranzler, 1995; Pajares \& Miller, 1994) rather than achievement-related behaviors (Onatsu-Arvilommi \& Nurmi, 2000). It is possible, however, that it is the ways in which children try to handle the school tasks rather than their mathrelated beliefs that play an important role in their mathematical performance. Third, previous studies have concerned older school-age children or adolescents (Campbell \& Beaudry, 1998; Galloway, Leo, Rogers, \& Armstrong, 1995; Jacobs, 1991; Pajares \& Graham, 1999; Pajares \& Kranzler, 1995; Pajares \& Miller, 1994) and only a few have dealt with children entering the primary school (Alexander \& Entwisle, 1988; Onatsu-Arvilommi \& Nurmi, 2000; Onatsu-Arvilommi, Nurmi, \& Aunola, 2000). The entrance into primary school might be assumed to be a particularly important developmental period, because during it children are for the first time faced with a challenge to master the basic academic skills (Alexander \& Entwisle, 1990) and also receive systematic feedback on their performance (Onatsu-Arvilommi \& Nurmi, 2000). Consequently, the present study focused on investigating the developmental dynamics between children's task-focused versus task-avoidant behaviors and their mathematical performance during the first 
school year.

Parental beliefs have been found to provide a basis for children's mathrelated attitudes and beliefs: children who show a high level of self-concept of math ability, who expect success, and who have positive math attitudes, come from families where parents believe in their offsprings' abilities to do well in mathematics (Frome \& Eccles, 1998; Huntsinger et al., 1997; Jacobs, 1991; Murphey, 1992; Parsons et al., 1982; Phillips, 1987; Stevenson \& Nyman, 1986; Wagner \& Phillips, 1992). In turn, children who see math as difficult and have low expectations for their future math performance come from families were parents believe that their children are not very good at math (Entwisle \& Baker, 1983; Phillips, 1987; Phillips \& Zimmerman, 1990; Stevenson \& Nyman, 1986).

Parental beliefs have also been shown to be associated with children's mathematical performance: parents who believe in their children's math competencies have children who do well in mathematics (Entwisle \& Alexander, 1990; Entwisle \& Baker, 1983; Galper et al., 1997; Hess et al., 1984; Huntsinger et al., 1997; Jacobs, 1991). It has also been suggested that the impact of parental beliefs on children's math performance may be mediated by the children's own achievement-related beliefs and behaviors (Eccles, 1993; Jacobs, 1991; Murphey, 1992).

However, previous research on the relationships between parental beliefs, children's achievement beliefs and behaviors, and their mathematical performance has one major limitation. The prospective relationships between parents' beliefs, and their children's achievement-related beliefs and behaviors, and their mathematical performance have not been investigated by using crosslagged longitudinal data. It might be assumed that it is parents' beliefs that influence children's achievement-beliefs and behaviors (Frome \& Eccles, 1998; Jacobs, 1991; Louis \& Lewis, 1992; Miller, 1986; Parsons et al., 1982; Phillips, 1987), and subsequently their mathematical performance. Another alternative, however, is that children's performance is reflected in their parents' beliefs (Frome \& Eccles, 1998; Miller, 1988). Consequently, this study focused on investigating the prospective relationships between parents' beliefs, children's achievement-related behaviors and their mathematical performance.

Most earlier studies of parental beliefs and children's performance have focused on one particular set of beliefs (Miller, 1988). Some studies have focused on parental beliefs concerning a particular skill, such as math or reading (Frome \& Eccles, 1998; Galper et al., 1997; Parsons et al., 1982; Phillips, 1987), whereas others have investigated more general beliefs concerning children's overall achievement (Alexander \& Entwisle, 1988; Hess et al., 1984; Peet, Powell, \& O'Donnel, 1997). Only a few studies have investigated both general and skillspecific beliefs (Baker \& Entwisle, 1987). In the present study, both parents' general beliefs in their children's competence at school, and their skill-specific beliefs concerning their offsprings' mathematical competence in particular, were investigated. 


\section{Aims of the study}

This study focused on investigating the developmental dynamics between children's achievement-related behaviors and their mathematical performance, and their mothers' and fathers' beliefs about their offsprings' competencies at school. The following research questions were examined:

(1) To what extent do the task-focused versus task-avoidant behaviors children deploy at school predict their subsequent mathematical performance, or is it rather the children's mathematical performance that predict their behaviors?

(2) To what extent do parents' general beliefs about their offsprings's school competence, and their skill-specific beliefs concerning mathematics, predict their children's mathematical performance later on?

(3) To what extent do parents' general beliefs and math-related beliefs predict their children's use of task-focused versus task-avoidant behaviors? And, in particular, to what extent is the impact of parental beliefs on children's mathematical performance mediated by the behaviors children show at school?

(4) To what extent do the task-focused versus task-avoidant behaviors children show at school and their mathematical performance contribute to their parents' subsequent general and math-related beliefs?

\section{METHOD}

\section{Participants and procedure}

\section{Children}

A total of 111 (59 boys, 52 girls) 6- to 7-year old children $(M=7.30, S D=0.32$ ) participated in the study. They came from six first-grade classes in four primary schools situated in a medium-size town in Central Finland. ${ }^{1}$ A total of $77 \%$ of the participants were from families with two parents, $9 \%$ of the families consisted of the mother or the father living with her/his new spouse and their children, and $13 \%$ of children were living with their single mother or father. The number of the children in the families range from 1 to $7(M=2.46, S D=1.05)$.

The children were examined five times during their first school year. First, their pre-mathematical skills were tested in August, at the beginning of the school year. Then, they were subsequently tested four times during their first school year - in October, December, January and April - using the Mathematical Skill Test (Lerkkanen, 1998). In the same time periods, participants' behavior in the classroom context was rated by their teacher using the Behavioral Strategy Rating Scale (BSR; Onatsu \& Nurmi, 1995).

\footnotetext{
${ }^{1}$ Children in Finland start school (elementary school level) in August of the year they reach the age of seven. Before going to primary school, most children have a year in pre-school.
} 


\section{Parents}

A questionnaire was mailed twice to the both parents of the children: in October and April. Parents were asked to fill in the questionnaires independently of each other. In October, a total of 96 mothers $(86.5 \%)$ returned the questionnaire; and in April, $92(82.9 \%)$ of them returned it. In October, $82(73.9 \%)$ of the fathers returned the questionnaire; and in April, 65 (58.6\%) of them returned it. A total of $30 \%$ of mothers and $35 \%$ of fathers had a degree from an institution of university standing, $63.5 \%$ of mothers and $58.5 \%$ of fathers had a degree from an institution of professional or vocational education, and $6.5 \%$ of mothers and fathers had no occupational education.

To investigate the possible selection effect, children whose mother or father filled in the questionnaire at time 1 and time 2 were compared with children whose mother or father did not return the questionnaires according to the mathematical performance and task-focused versus task-avoidant behaviors variables. No selection effect was found in the case of mothers. However, the children whose father participated the study at time 1 showed a higher level of task-focused behavior than children whose father did not participate at time 1 ( $F$ $(1,106)=5.74, p<.05)$.

\section{Measurements}

\section{Children's measures}

Premeasurement. Children's pre-mathematical skills at the beginning of the primary school were measured with the Number Concept Test (Liikanen, 1984). In this test, children were read aloud 24 questions, consecutively, and asked to mark down the answers on the separate answer sheet. The questions assessed three kinds of mathematical knowledge or skills: (1) mathematical concepts, such as 'last', 'middle', 'nearest', 'between', and 'before' (e.g. "Draw a line over the shovel in the middle."); (2) ordinal- and cardinal numbers (e.g. "Draw a line over nine leaves."); (3) addition, subtraction, division and multiplication skills (e.g." You have four pears. You get an equal amount more. Draw a line over the number of pears you now have."; "Eeva has two balls. Kirsti has twice as many balls as Eeva has. Draw a line over the number of balls Kirsti has.").

The maximum score for the test was 24. Because the score for the Number Concept Test was not normally distributed $(z=1.80, p<.01)$, a new score was computed by combining the original values to make the distribution resemble the normal. The new score was computed as follows: values $6-12=1$, values $13-15$ $=2$, value $16=3$, value $17=4$, value $18=5$, value $19=6$, value $20=7$, value $21=$ 8 , value $22=9$, value $23=10$, value $24=11$. The Cronbach alpha reliability for this test has been shown to be .82 (Ljungblad, 1971).

Mathematical performance. Children's mathematical performance was assessed by the use of the Mathematical Skill Test (Lerkkanen, 1998). The tasks were modified from the Diagnostic Tests 3: Motivation, metacognition and mathematics (Salonen, Lepola, Vauras, Rauhannummi, Lehtinen, \& Kinnunen, 1994). The structure of the test was similar at all measurement points. However, the tasks included in the test became progressively more difficult across the measurement points as the children became more skilled in mathematics. The test consisted of 
three parts:

(1) The mathematical-logical reasoning part consisted of four verbal mathematical problems, which each assessed different aspects of reasoning (transitive reasoning, number conservation, class inclusion, logical reasoning). The problems were read aloud to the participants twice. After each problem, the participants were asked to choose and mark down the right solution on the paper.

(2) The number sequence part consisted of four questions or tasks assessing children's knowledge of ordinal aspects of numbers (forward and backward). In the first and second measurements, children were read aloud four questions (e.g. "What number is after number five?"; "What is the number you get when you count five numbers backward from nine?") and asked to write the answers down. In the third and fourth measurements, the children's task was to complete four rows of numbers (e.g. "2, 4, 6, , 10, 12"; “18, 17, , 15, 14, 13").

(3) The basic arithmetic skill part consisted of a set of addition (e.g. " $9+5=$ ${ }_{-}$; "7 + _ = 14") and subtraction (e.g. "17-9 = _"; "15 _ _ =9") tasks (12 tasks in the first measurement; 16 tasks in the second, third, and fourth measurements). Children were asked to do as many of them as they could.

In the Mathematical Skill Test, one point was given for each correct answer. The total maximum score for the test was 20 in the first measurement and 24 in the second, third and fourth measurements. The Cronbach alpha reliabilities for the Mathematical Skill Test were .61, .72, .80, and .75, respectively at four measurement points.

The mathematical-logical reasoning tasks are similar to those used earlier by Pajares and Miller (1994). The tasks in the number sequence- and basic arithmetic skill -parts are similar to those used earlier, for example, by Newcomer and Curtis (DAP-2; 1984-90), and McCarney and Bauer (LDES; 1983-91).

Task-focused versus task-avoidant behaviors. The classroom teachers of each of the four first-grade classes involved in the study were asked to evaluate the behavior of each pupil in their class using the Behavioral Strategy Rating Scale (BSR; Onatsu \& Nurmi, 1995; Onatsu-Arvilommi \& Nurmi, 2000). They were first asked to consider and remind themselves how a certain pupil typically behaved in classroom situations, and then rate his or her behavior using 5 statements (e.g. "Does the pupil have a tendency to find something else to do instead of focusing on the task at hand?", reversed; "Does the pupil show persistence even in the more difficult tasks?") assessed on a 5-point rating scale ( $0=$ "Not at all", $4=$ "To a great extent"). A summary score was formed for each pupil's task-focused versus task-avoidant behavior. Later on, the term task-focused behavior is used to refer this. The Cronbach Alpha reliabilities for the summary-score were .95, .94, .95, and .96, respectively at the four measurement points. The task-focused versus taskavoidant behavior scale of BSR has been shown to correlate moderately with children's self-reported task-focused behavior (.30) (Nurmi \& Aunola, 2000; Onatsu \& Nurmi, 1997) and also with observers' rating of it (.42) (Nurmi \& Aunola, 2000).

\section{Parents' measurement}

The parents' beliefs about their children's school competence were assessed with four 4-point Likert items modeled from the questionnaires of Parsons [Eccles] et 
TABLE 1 Pearson Product-Moment Correlations Between Manifest Variables and their Means and Standard Deviations.

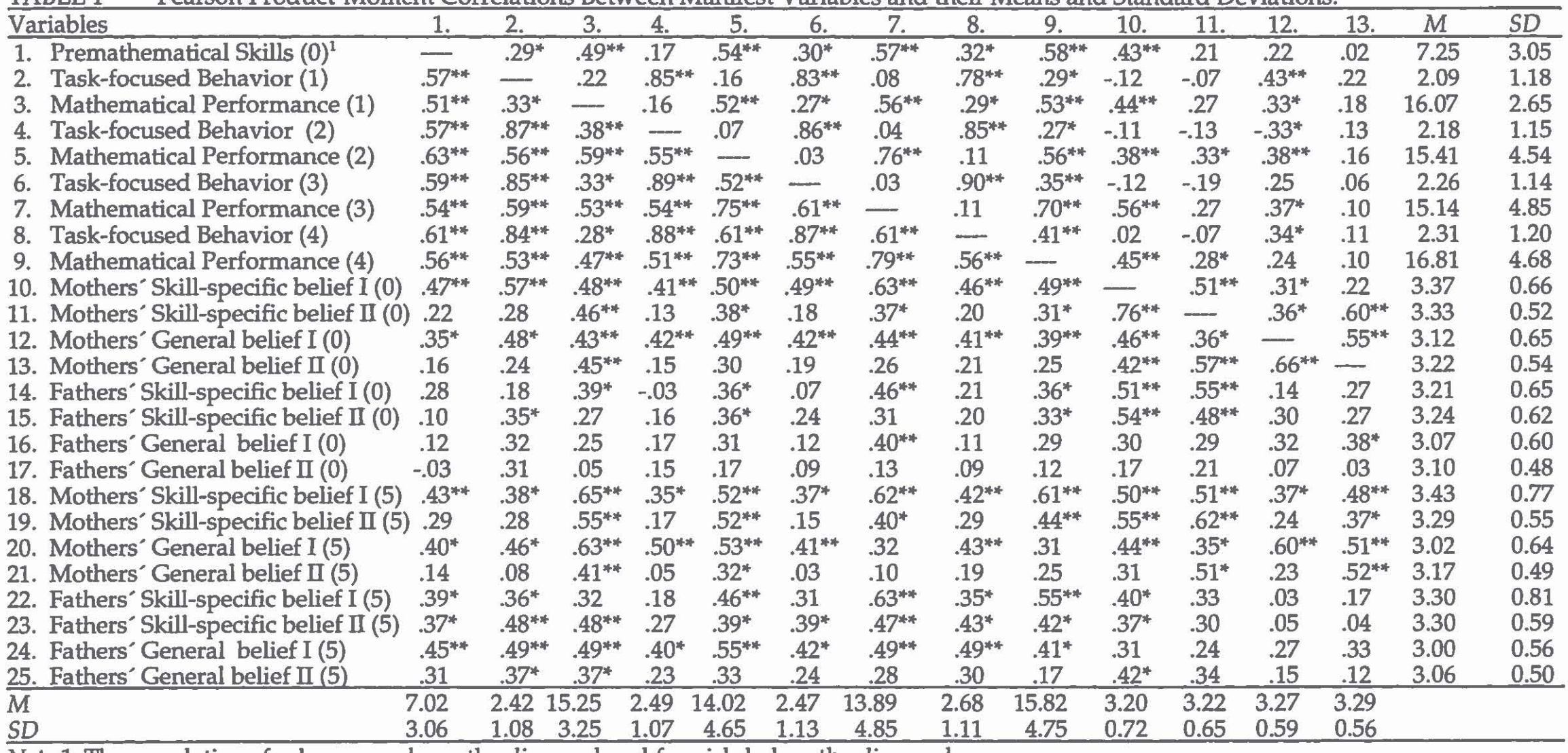

Note 1. The correlations for boys are above the diagonal and for girls below the diagonal.

Note 2. ${ }^{*} p<.05 ;{ }^{* *} p<.01$. $0=$ Premeasurement; $1=$ Measurement $1 ; 2=$ Measurement $2 ; 3=$ Measurement 3; $4=$ Measurement 4;

$5=$ Measurement 5

Note 3. ${ }^{1}$ Revised score. 
TABLE 1 (continues)

\begin{tabular}{|c|c|c|c|c|c|c|c|c|c|c|c|c|}
\hline Variables & 14. & 15. & 16. & 17. & 18. & 19. & 20. & 21. & 22. & 23. & 24. & 25. \\
\hline 1. Premathematical Skills $(0)^{1}$ & $.35^{*}$ & $.31^{*}$ & .12 & -.03 & .26 & .18 & $.31^{*}$ & .11 & $.47^{* *}$ & .33 & .17 & -.03 \\
\hline 3. Mathematical Performance (1) & $.51^{* *}$ & .29 & .22 & .08 & $.32^{*}$ & $.45^{* *}$ & $.37^{*}$ & $.39^{*}$ & $.35^{*}$ & $.38^{*}$ & .19 & .13 \\
\hline 4. Task-focused Behavior (2) & .19 & .01 & .24 & .05 & -.05 & .05 & $.39^{*}$ & .18 & -.02 & .05 & $.38^{*}$ & .07 \\
\hline 6. Task-focused Behavior (3) & .29 & .08 & .27 & .23 & -.10 & .00 & $.47^{* *}$ & .15 & .01 & .24 & $.44^{* *}$ & .21 \\
\hline 7. Mathematical Performance (3) & $.48^{* *}$ & 16 & .24 & -.09 & $.51^{* *}$ & .21 & .21 & -.04 & $.60^{* *}$ & .07 & .10 & -.20 \\
\hline 8. Task-focused Behavior (4) & $.32^{*}$ & .05 & .21 & .15 & -.06 & .01 & $.54^{* *}$ & .13 & -.07 & .12 & $.34^{*}$ & .11 \\
\hline 9. Mathematical Performance (4) & $.54^{* *}$ & .18 & $.35^{*}$ & .18 & $.41^{* *}$ & .21 & .29 & .17 & $.53^{* *}$ & .29 & .21 & -.08 \\
\hline 12. Mothers' General belief I ( 0 ) & .31 & -.06 & $.46^{* *}$ & .00 & .23 & .27 & $.56^{* *}$ & $.35^{*}$ & $.36^{*}$ & .03 & .22 & -.04 \\
\hline 13. Mothers' General belief II ( 0 ) & .14 & .14 & .31 & .18 & $.36^{*}$ & $.42^{* *}$ & $.46^{* *}$ & $.48^{* *}$ & $.54^{* *}$ & .25 & .21 & .31 \\
\hline 14. Fathers' Skill-specific belief I ( 0 ) & $\ldots$ & $.48^{* *}$ & $.54^{* *}$ & $.32^{*}$ & $.49^{* *}$ & .14 & $.48^{* *}$ & .12 & $.57^{* *}$ & $.43^{*}$ & .17 & -.04 \\
\hline 15. Fathers' Skill-specific belief II (0) & $.53^{* *}$ & $\ldots$ & .28 & $.41^{* *}$ & .24 & .26 & .31 & .18 & $.44^{*}$ & $.67^{* *}$ & .18 & $.38^{*}$ \\
\hline 16. Fathers' General belief I $(0)$ & $.49^{* *}$ & 18 & $\ldots$ & $.56^{* *}$ & .25 & .10 & $.48^{* *}$ & .14 & $.50^{* *}$ & $.48^{* *}$ & $.44^{*}$ & .23 \\
\hline 17. Fathers' General belief II ( 0 ) & .29 & .28 & $.46^{* *}$ & $\ldots$ & .13 & .11 & $.44^{*}$ & .15 & .11 & $.47^{* *}$ & .35 & $.49 * *$ \\
\hline 18. Mothers' Skill-specific belief I (5) & $.57^{* *}$ & .18 & $.38^{*}$ & $.37^{*}$ & $\ldots$ & $.45^{* *}$ & .23 & .26 & $.58^{* *}$ & .19 & .07 & -.07 \\
\hline 24. Fathers' General belief I (5) & $.47^{* *}$ & $.43^{*}$ & $.37^{*}$ & $.47^{* *}$ & $.58^{* *}$ & $.39^{* *}$ & $.56^{* *}$ & $.51^{* *}$ & $.66^{* *}$ & $.70^{* *}$ & 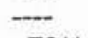 & $.56^{* *}$ \\
\hline 25. Fathers' General belief II (5) & $.44^{*}$ & $.39 *$ & .30 & $.49^{* *}$ & $.49^{* *}$ & $.46^{* *}$ & $.48^{* *}$ & $.54^{* *}$ & $.57^{* *}$ & $.76^{* *}$ & $.78^{* *}$ & $\ldots$ \\
\hline$M$ & 3.10 & 3.24 & 3.27 & 3.32 & 3.02 & 3.10 & 3.24 & 3.21 & 2.84 & 3.16 & 3.19 & 3.28 \\
\hline$\underline{S D}$ & 0.74 & 0.64 & 0.61 & 0.47 & 0.88 & 0.73 & 0.58 & 0.52 & 0.92 & 0.63 & 0.74 & 0.58 \\
\hline
\end{tabular}


al. (1982) and Frome and Eccles (1998). Two of these items measured parents ${ }^{\prime}(1)$ Skill-specific beliefs ("How well do you think your child is doing in mathematics?"; "How well do you think your child will do in mathematics later in school?") and two of them measured their (2) General beliefs ("In general, how well is your child doing at school?"; "In general, how well do you think your child will do at school later on?").

\section{RESULTS}

The statistical analyses were carried out by the use of structural equation modelling (SEM) with the LISREL8 statistical package (Jöreskog \& Sörbom, 1993). The parameters of the model were estimated using the Maximum Likelihood (ML) procedure. The goodness-of-fit was evaluated using three indicators, $\chi^{2} / \mathrm{df}$, Bentler's (1990) Comparative Fit Index (CFI), and Bentler and Bonnet's (Bentler, 1990) Non-Normed Fit Index (NNFI), as suggested by Gerbing and Anderson (1993). In order to investigate whether an identical model would fit for boys and girls, a multisample procedure suggested by Jöreskog and Sörbom (1993) was used. The sample correlation matrix, and means and standard deviations for the measured variables are presented in Table 1, separately for boys and girls.

In all the tested models, the constructs for mathematical performance and task-focused behavior (time 1, 2, 3 and 4), and pre-mathematical skills (time 0) consisted of one indicator. Consequently, their loadings were set as equal to 1 with an error term 0 . The constructs for parents' skill-specific and general beliefs at time 0 and time 5 consisted of two indicators. For each of these constructs, one of the loadings were set equal to 1 (Table 2).

TABLE 2 Standardized Parameter Estimates for Parents' Skill-Specific and General Beliefs at Time 0 and Time 5 (the Final Model).

\begin{tabular}{lll}
\hline Variable & Time 0 & Time 5 \\
\hline Mkill-specific belief I & 0.82 & 0.77 \\
Skill-specific belief II & 0.74 & 0.64 \\
General belief I & 0.86 & 0.89 \\
General belief II & 0.71 & 0.53 \\
$\quad$ Fathers & 0.93 & 0.90 \\
Skill-specific belief I & 0.56 & 0.74 \\
Skill-specific belief II & 0.84 & 1.00 \\
General belief I & 0.61 & 0.67 \\
General belief II & &
\end{tabular}

\section{Task-focused behavior and mathematical performance}

First, a structural model using a multisample procedure was constructed to examine the extent to which task-focused behavior prospectively predicted mathematical performance, and the extent to which mathematical performance prospectively predicted task-focused behavior. Besides stability coefficients, this model included paths from task-focused behaviors to subsequent mathematical performance measurement, and from mathematical performance to subsequent 
task-focused behavior. In order to control the preliminary level of mathematical skills at the beginning of the school year, the pre-mathematical skill variable was included in the model at measurement 0 .

The model fitted the data well $\left(\chi^{2}=110.17, \mathrm{df}=67 ; C F I=0.94 ; N N F I=0.94\right)$. However, after omitting the nonsignificant paths $\left(\chi^{2}=113.09, \mathrm{df}=71 ; C F I=0.94\right.$; $N N F I=0.94)$, the modification indices suggested that the fit of the model would be increased by estimating the error covariances between (1) the task-focused behavior variable at time 2 and that of time 3 for the whole sample; and (2) the task-focused behavior construct at time 1 and the mathematical performance construct at time 2 among boys. After these specifications, none of the indices exceeded the value 8 , suggesting that the model fitted both girls and boys data well $\left(\chi^{2}=86.18, \mathrm{df}=69 ; \mathrm{CFI}=0.98 ; \mathrm{NNFI}=0.98\right.$; the percentage contribution to $\chi^{2}$ was $44.03 \%$ for girls and $56.97 \%$ for boys). The standardized beta coefficients for this model are presented in Figure 1.

Time0

Time 1

Time 2

Time3

Time 4

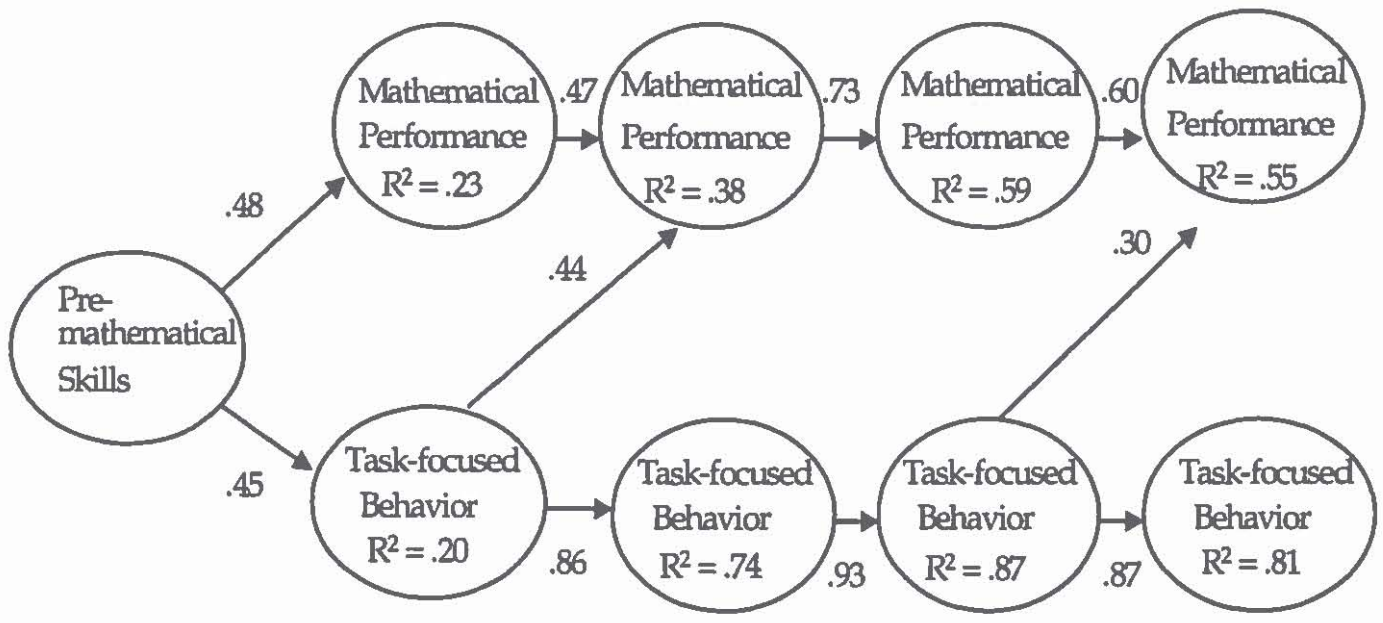

FIGURE 1 Results of SEM for Children's Task-Focused Behavior and Mathematical Performance.

The results showed, first, that the level of children's pre-mathematical skills at the beginning of the school year (time 0) was positively associated with their mathematical performance and task-focused behavior at measurement 1 . Moreover, both mathematical performance and task-focused behavior were substantially stable across the four measurements.

Second, examination of the prospective relationships between mathematical performance and achievement-related behaviors revealed that a high level of task-focused behavior prospectively predicted high levels of mathematical performance both from time 1 to time 2 and from time 3 to time 4 . 
The role of mothers' beliefs in children's task-focused behavior and mathematical performance

Next, in order to examine the prospective relationships between mothers' beliefs, and their children's task-focused behavior and mathematical performance, maternal general and skill-specific beliefs at time 0 and time 5 were added to the previously-mentioned model. In this model, the constructs for mothers' general and skill-specific beliefs at the same measurement point were let to correlate. Moreover, the stability coefficients for maternal general and skill-specific beliefs were included in the model, as well as the paths from maternal beliefs to subsequent mathematical performance and task-focused behavior, and from these to subsequent maternal beliefs.

The model did not fit the data very well: $\chi^{2}=332.17, \mathrm{df}=255 ; C F I=0.92$; $N N F I=0.91$. After omitting the nonsignificant paths $\left(\chi^{2}=337.67, \mathrm{df}=259 ; C F I=\right.$ $0.92 ; N N F I=0.91$ ), the modification indices suggested that the fit of the model would be increased by estimating the error covariances between: (1) one of the general belief variables at time 0 and one of the skill-specific belief variables at time $0 ;(2)$ one of the general belief variables at time 5 and one of the skill-specific belief variables at time 5; and (3) one of the skill-specific belief variables at time 0 and one of the skill-specific belief variables at time 5 among boys. After these specifications, the model fitted both girls' and boys' data well $\left(\chi^{2}=285.27, \mathrm{df}=\right.$ 253; $C F I=0.97 ; N N F I=0.96$; the percentage contribution to $\chi^{2}$ was $53.44 \%$ for girls and $47.56 \%$ for boys.). The standardized beta coefficients for this final model are presented in Figure 2.

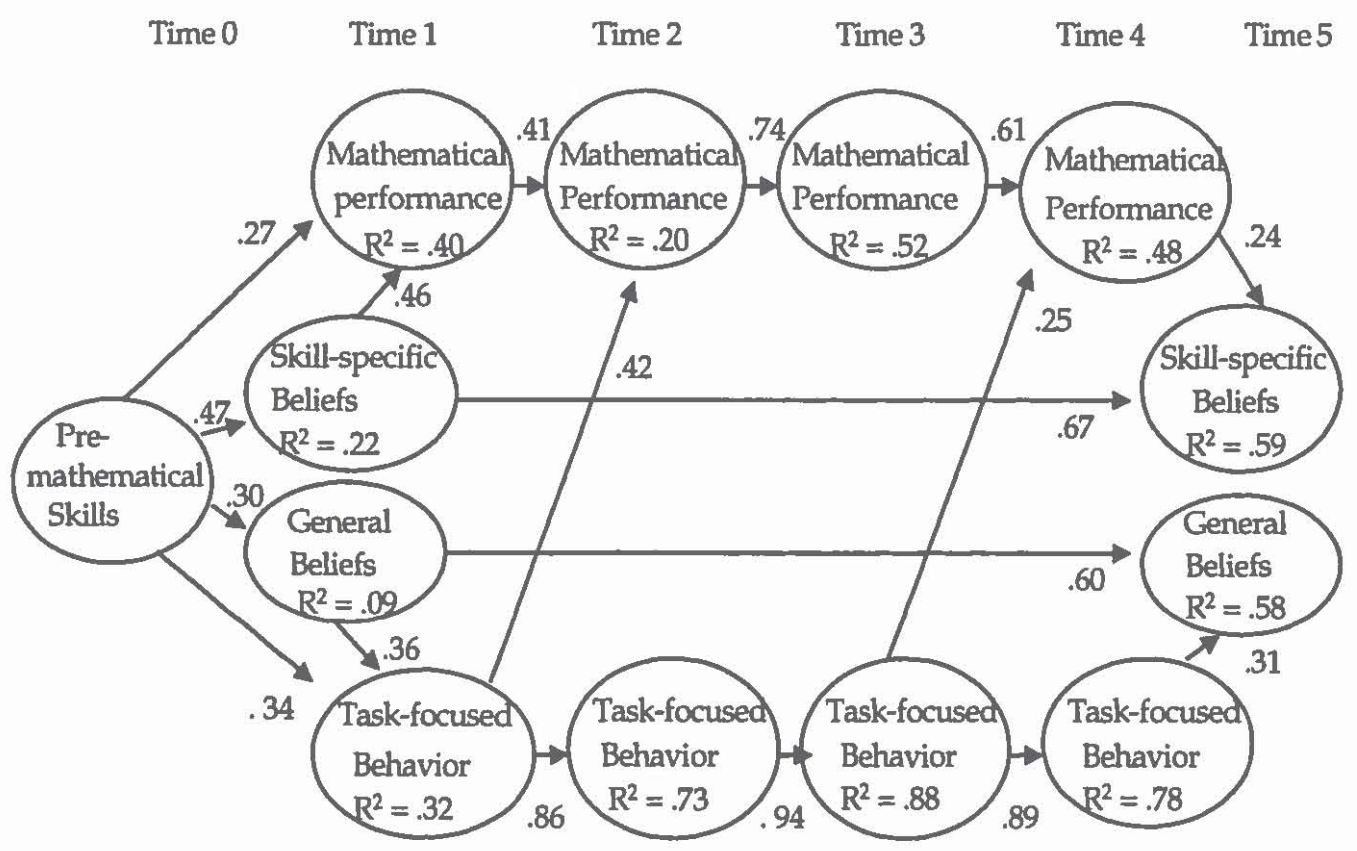

FIGURE 2 Results of SEM for Mothers' General and Skill-Specific Beliefs, and Children's Task-Focused Behavior and Mathematical Performance. 
The results showed that the pre-mathematical skills of the children were positively associated with the mothers' skill-specific and general beliefs: the higher the level of the children's pre-mathematical skills was at the beginning of the school year, the more their mothers believed in their children's abilities to do well at school in general, and in mathematics, in particular. Moreover, both the mothers' skill-specific and general beliefs showed substantial stability across the two measurements.

Second, the mothers' skill-specific beliefs at the beginning of the first school year predicted their children's level of mathematical performance at time 1: the higher confidence the mothers had in their children's math competence, the higher the level of mathematical performance the children showed later on. The results also showed that the children's mathematical performance predicted the mothers' subsequent skill-specific beliefs: the higher the level of mathematical performance the children showed at time 4, the more the mothers believed in their children's abilities to do well in mathematics, in particular.

Third, the mothers' general beliefs at the beginning of the first school year predicted their children's subsequent task-focused behavior at time 1: the better the mothers expected their children to do at school in general, the higher the level of task-focused behavior the children showed later on. Moreover, there was also an indirect impact from the mothers' general beliefs to the children's mathematical performance at time 2 through the children's task-focused behavior (Indirect effect standardized $=0.16, t=2.56$ ): in other words, the mothers' high beliefs in their children's general school competence increased the children's task-focused rather than task-avoidant behaviors, which further increased their subsequent performance in mathematics. Finally, the level of task-focused behavior the children showed in the classroom predicted the mothers' general beliefs at the end of the school year: the more task-focused behaviors the children showed at time 4 , the higher confidence the mothers had on their offsprings' school performance at the end of the school year.

\section{The role of fathers' beliefs in children's task-focused behavior and mathematical performance}

Next, an analogous model was tested for the fathers' data. The model fitted the data well $\left(\chi^{2}=284.17, \mathrm{df}=255 ; C F I=0.96 ; N N F I=0.96\right)$. However, after omitting the nonsignificant paths $\left(\chi^{2}=286.43, \mathrm{df}=258 ; C F I=0.96 ; N N F I=0.96\right)$, the modification indices suggested that the fit of the model would be increased by estimating the error covariance between one of the skill-specific belief variables at time 5 and one of the general belief variables at time 5 among boys. After this specification the fit of the model was good $\left(\chi^{2}=260.32, \mathrm{df}=256 ; C F I=0.99 ; N N F I\right.$ $=0.99$; the percentage contribution to $\chi^{2}$ was $45.59 \%$ for girls and $54.41 \%$ for boys). Standardized beta coefficients for this final model are presented in Figure 3. 


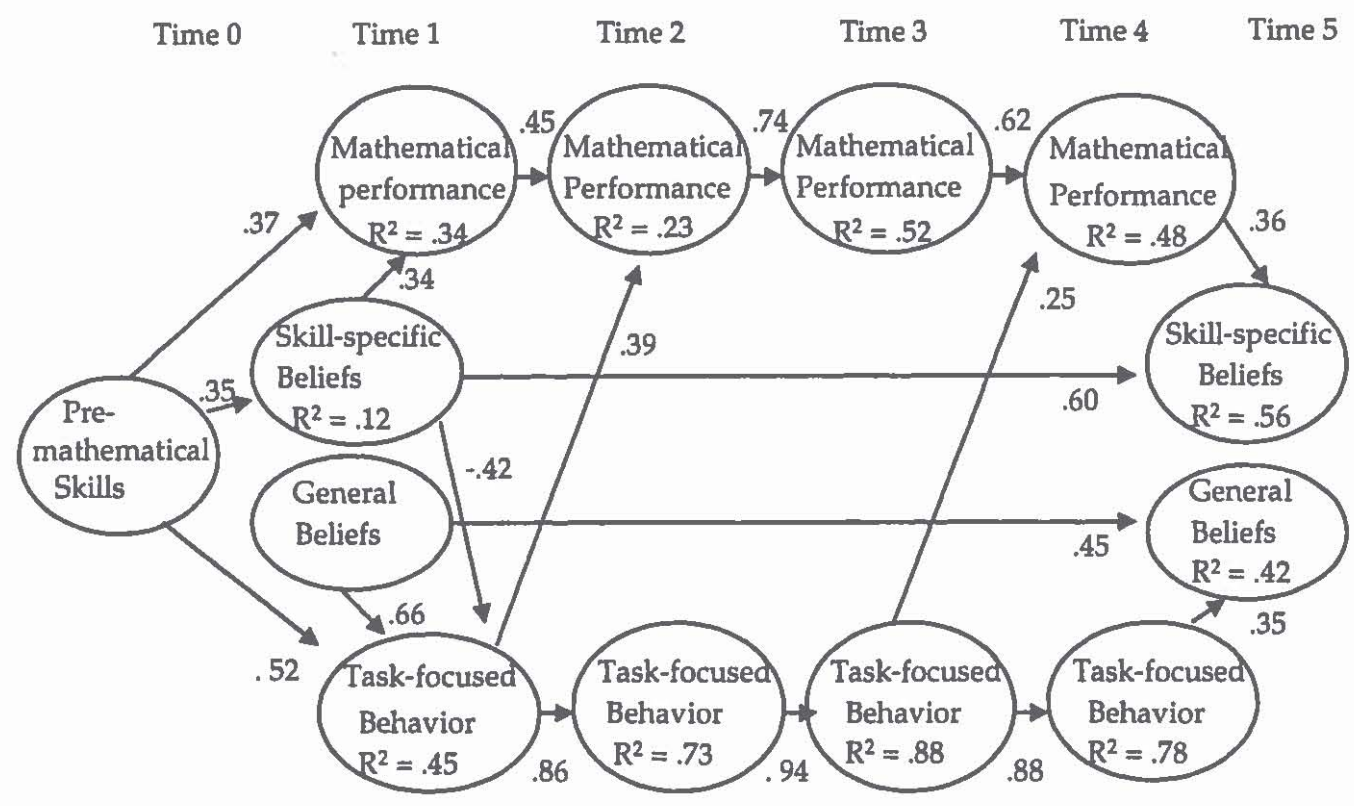

FIGURE 3 Results of SEM for Fathers' General and Skill-Specific Beliefs, and Children's Task-Focused Behavior and Mathematical Performance.

The results showed, first, that the pre-mathematical skills of the children were positively associated with the fathers' skill-specific beliefs: the higher the level of children's pre-mathematical skills was at the beginning of the school year, the more their fathers believed in their children's abilities to do well in mathematics, in particular. However, the premathematical skills did not predict the fathers' general beliefs. The fathers' skill-specific and general beliefs showed both substantial stability across the two measurements.

Second, the fathers' skill-specific beliefs at the beginning of the first school year predicted their children's mathematical performance at time 1: the higher confidence fathers had in their children's math competence, the higher level of mathematical performance the children showed later on. The results also showed that the children's mathematical performance predicted the fathers' subsequent skill-specific beliefs: the higher the level of mathematical performance the children showed at time 4, the more the fathers believed in their children's ability to do well in mathematics.

Third, the fathers' general beliefs at the beginning of the first school year predicted their children's subsequent task-focused behavior at time 1: the better the fathers expected their children to do at school in general, the higher the level of task-focused behavior the children showed later on. Moreover, there was an indirect impact from the fathers' general beliefs to the children's mathematical performance at time 2 through the children's task-focused behavior (Indirect effect standardized $=0.24, t=2.43$ ): the fathers' high beliefs in their children's general school competence increased the children's task-focused rather than task-avoidant behaviors, which further increased their subsequent performance in mathematics. Although there was a negative path from the fathers' skill-specific beliefs to the 
children's task-focused behavior, the correlation coefficient was positive $(r=.18)$. Finally, the level of task-focused behavior the children showed in the classroom predicted the fathers' general beliefs at the end of the school year: the more taskfocused behaviors the children showed at time 4 , the higher confidence the fathers had in their offsprings' school performance at the end of the school year.

The results for both fathers and mothers were closely analogous. Only one of the tested paths were different for mothers and fathers: the children's premathematical skills did not predict the fathers' general beliefs as they did among the mothers.

\section{Mean and gender differences in the levels of parental beliefs}

In order to investigate the mean differences in the parental beliefs, two-way multivariate analyses of variance with one within-subject factor (Time: Measurement 0 vs. Measurement 5 ) and one between-subject factor (Gender of the Child) were carried out separately for general beliefs and skill-specific beliefs. These analyses were carried out separately for mothers and fathers. The sum scores were created for each construct by multiplying each individual variable by its factor loading in the (final) measurement model presented in Table 2, and calculating the means across these variables. The means and standard deviations for the variables at the three measurement points are presented in Table 3, separately for girls and boys.

TABLE 3 Means (M) and Standard Deviations (SD) of Parents` Beliefs for Girls and Boys, Separately.

\begin{tabular}{|c|c|c|c|c|c|}
\hline \multirow[t]{2}{*}{ Variable } & \multirow[t]{2}{*}{ Gender } & \multicolumn{2}{|c|}{ Measurement 0} & \multicolumn{2}{|c|}{ Measurement 5} \\
\hline & & $\bar{M}$ & $S D$ & $M$ & $\overline{S D}$ \\
\hline Mothers & & & & & \\
\hline \multirow{2}{*}{ Skill-specific beliefs } & Girls & 5.00 & 1.00 & 4.31 & 1.08 \\
\hline & Boys & 5.23 & 0.81 & 4.74 & 0.82 \\
\hline \multirow[t]{2}{*}{ General beliefs } & Girls & 5.15 & 0.83 & 4.59 & 0.71 \\
\hline & Boys & 4.96 & 0.84 & 4.37 & 0.73 \\
\hline \multirow{3}{*}{$\begin{array}{l}\text { Fathers' } \\
\text { Skill-specific beliefs }\end{array}$} & & & & & \\
\hline & Girls & 4.71 & 0.93 & 4.90 & 1.24 \\
\hline & Boys & 4.80 & 0.82 & 5.42 & 1.04 \\
\hline \multirow[t]{2}{*}{ General beliefs } & Girls & 4.77 & 0.69 & 5.39 & 1.07 \\
\hline & Boys & 4.47 & 0.71 & 5.05 & 0.80 \\
\hline
\end{tabular}

Among mothers, the main effects for gender or Time $x$ Gender interaction were not statistically significant in either of the analyses. However, the main effect for time was statistically significant for the mothers' general $(F(1,76)=45.29, p<$ $.001)$ and skill-specific $(F(1,76)=37.40, p<.001)$ beliefs: the mothers reported a lower level of general and math-specific beliefs at the end of the school year than at the beginning.

Among the fathers, a statistically significant main effect for Time $x$ Gender interaction was found for the skill-specific beliefs: the fathers' reported a higher 
beliefs in their son's and a lower beliefs in their daughter's mathematical performance at the end of the school year than at the beginning $(F(1,60)=3.99$, $p$ $<.05)$. The analyses for the fathers' general beliefs revealed no significant main effects for Time $x$ Gender interaction or gender. However, the main effect for time was significant: the fathers' general beliefs increased across the two measurements $(F(1,60)=36.26, p<.001)$.

\section{DISCUSSION}

This study focused on investigating the developmental dynamics between parental beliefs, children's achievement-related behaviors and their mathematical performance. Overall, the results revealed that the impact of parents' beliefs concerning their offsprings' general school competence on children's math performance was mediated via the child's task-focused versus task-avoidant behavior at school (Eccles, 1993). By contrast, parents' beliefs in their children's competence in mathematics contributed directly to their children's high performance. Moreover, children's high mathematical performance was reflected in parents' subsequent beliefs in their children's mathematical competence, whereas children's task-focused behaviors increased parent' ${ }^{\prime}$ beliefs in their children's overall school competence.

The first aim of this study was to investigate the prospective relationships between children's task-focused versus task-avoidant behaviors, and their performance in mathematics, during their first school year. The results revealed that the achievement-related behaviors children displayed in the classroom contributed to their math-skill development: children's high level of task-focused behaviors increased their subsequent improvement in mathematics, whereas their high-level of task-avoidance decreased it. This result accords well with previous cross-sectional findings on the role of children's and adolescents' achievementrelated beliefs, such as self-concept of ability (Campbell \& Beaudry, 1998; Jacobs, 1991; Marsh et al., 1991; Pajares \& Miller, 1994), self-efficacy (Pajares \& Graham, 1999; Pajares \& Kranzler, 1995), and success expectations (Alexander \& Entwisle, 1988; Jacobs, 1991), in their mathematical performance. The results of the present study suggest that, in addition to achievement beliefs, the related behaviors at school also play an important role in children's math performance. Moreover, the present study adds to the previous literature by showing that it is the achievement-related behaviors that contribute to the math performance rather than vice versa. Overall, the results suggest that school pupils with learning difficulties in mathematics may benefit from efforts to change their achievementrelated beliefs in order to motivate them to deploy a task-focused rather than a task-avoidant behavior in the classroom (Onatsu-Arvilommi \& Nurmi, 2000).

The second aim of this study was to investigate the extent to which parents' beliefs in their offsprings' competence would predict their children's mathematical performance and whether this impact is mediated by the achievement-related behaviors children deploy at school. The results showed that the impact of parents' general beliefs on their offsprings' mathematical 
performance was mediated by the children's achievement-related behavior: parents' high beliefs in their offsprings' academic competence increased their children's task-focused behavior, which, in turn, improved their subsequent performance in mathematics. These results accord well with previous crosssectional findings. It has been found that parental beliefs are associated with children's own achievement related beliefs (Frome \& Eccles, 1998; Jacobs, 1991; Murphey, 1992; Parsons et al., 1982; Phillips, 1987; Stevenson \& Nyman, 1986; Wagner \& Phillips, 1992), which, in turn, have been found to be related to children's mathematical performance (Pajares \& Graham, 1999; Pajares \& Kranzler, 1995). The results of the present study add to this literature by providing direct support for the notion that children's self-perceptions and task-orientations mediate the impact of parental beliefs on their academic achievement (Murphey, 1992; Parsons et al., 1982; Phillips, 1987). There are, however, many possible reasons for this particular result. For example, parents' general beliefs and related child-rearing practices may provide a basis for their children's own selfperceptions (Frome \& Eccles, 1998; Parsons et al., 1982; Stevenson \& Newman, 1986) and, consequently, their task-focused or task-avoidant behavior, which is then reflected in their mathematical performance. Another possibility is that parents' general beliefs about their children's academic competencies are associated with authoritative parenting styles (Murphey, 1992), the effective scaffolding (Pratt, Green, MacVicar, \& Bountrogianni, 1992), and rational guidance (Maccoby \& Martin, 1983), which have been shown to motivate children's active problem solving attempts and task-focused behavior (Ginsburg \& Bronstein, 1993; Onatsu-Arvilommi, Nurmi, \& Aunola, 1998), and high subsequent performance.

The results further showed that children's achievement-related behavior was reflected in their parents' general beliefs: the more task-focused behaviors children deployed at school the more their parents' believed in their children's overall competence at school, whereas the more task-avoidance they showed the less the parents believed in their competence. These results suggest that besides school performance children's school-related behaviors also provide information for parents about how the child will do at school in the future.

The results revealed, however, that parents' skill-specific beliefs predicted their offsprings' mathematical performance directly: children whose parents believed in their offsprings' abilities in mathematics performed well in mathematics later on. This was true even after controlling for the level of children's mathematical skills at the beginning of the school year. This result is consistent with many previous cross-sectional findings (Entwisle \& Alexander, 1990; Galper et al., 1997; Hess et al., 1984; Stevenson \& Newman, 1986). One explanation for the results of the present study is that parents who believe in their children's abilities in mathematics provide more challenging tasks and opportunities for their children to practice math-related problem solving skills (Musun-Miller \& Blevins-Knabe, 1998). It is also possible that parents who believe in their children's abilities in mathematics themselves perform well in math and have positive attitudes toward mathematics (Huntsinger et al., 1997), and, consequently, also encourage their children in math-related activities. The results also showed that children's performance in mathematics was reflected in their 
parents' math-related beliefs: high performance in mathematics enhanced parents' positive beliefs about their offsprings' mathematical competence. This result supports earlier cross-sectional findings (Parsons et al., 1982; Phillips, 1987), suggesting that parental beliefs reflect children's actual skill level. This result also fit well with the notion that school feedback has a 'corrective' effect on parents' beliefs (Entwisle \& Hayduk, 1978).

The relationships between children's achievement-related behaviors and mathematical performance, and their parents' beliefs, were highly similar for boys and girls. Similarly, the results for both fathers and mothers were closely analogous. However, the results showed gender differences in how fathers perceived their son's and daughters' skills: fathers' beliefs in their sons' mathematical performance increased across the school year, whereas the opposite was true for girls. This result support the earlier notions that parents tend to socialize their sons and daughters in a stereotypical ways, expecting girls to be less competent in mathematics (Jacobs, 1991; Lummis \& Stevenson, 1990). However, the results of the present study did not support this notion among mothers.

There are some grounds for caution in making generalizations on the basis of the results presented here. First, although a cross-lagged longitudinal study was carried out, it is possible that there were some other variables behind the obtained path coefficients. For example, it is likely that there is a shared genetic background behind the parents' and children's math performance (Miller, 1988), which may be reflected in their attitudes. Second, because the sample size of this study was relatively small, particularly concerning the fathers' data, the results of structural equation modelling must be interpreted with caution. Third, the present study focused on children's teacher-rated behaviors at school and no information was gathered from children's achievement beliefs. In future research, there is a need to use a multiple-informant approach to gather data on both children's beliefs and their behaviors. In such research, it is also possible to examine the extent to which the impacts of children's beliefs on their performance is mediated by the behaviors they show. Finally, this study included self-report data on parents' expectations. In future studies, it would also be important to have information about how parents' expectations are reflected in their parenting behaviors.

Overall, the results of the present study add to previous research on the role of achievement-related motivation, beliefs and behaviors in children's math skill development in at least three ways. First, the present study showed that besides children's math-related beliefs (Jacobs, 1991; Marsh et al., 1991; Pajares \& Kranzler, 1995; Pajares \& Miller, 1994) their achievement-related behaviors, such as focusing on task or task-avoidance, also play an important role in their mathematical performance. Second, the present study showed that parents' beliefs did not only provide a basis for their children's mathematical performance both directly, and indirectly via children's behaviors, but that children's performance and behavior also had an impact on their parents' beliefs. Third, the results suggested that not only children's achievement-related beliefs and strategies, and their mathematical competence, form positive or negative developmental cycles, but also that parental beliefs are part of such a self-perpetuating, cumulative cycle. 


\section{REFERENCES}

Alexander, K. L., \& Entwisle, D. R. (1988). Achievement in the first two years of school: Patterns and processes. Monographs of the Society for Research in Child Development, 53 (2, Serial No. 218).

Armstrong, J. M. (1985). A national assessment of participation and achievement of women in mathematics. In S. F. Chipman, L. R. Brush, \& D. M. Wilson (Eds.), Women and mathematics: Balancing the equation (pp. 59-94). Hillsdale, NJ: Erlbaum.

Ashcraft, M. H., Kirk, E. P., \& Hopko, D. (1998). On the cognitive consequences of mathematics anxiety. In C. Donlan (Ed.), The development of mathematical skills. Studies in developmental psychology (pp. 175-196). East Sussex, England: Psychology Press a member of the Taylor \& Francis group.

Baker, D. P., \& Entwisle, D. R. (1987). The influence of mothers on the academic expectations of young children: A longitudinal study of how gender differences arise. Social Forces, 65, 670-694.

Bentler, P. M. (1990). Comparative fit indexes in structural models. Psychological Bulletin, 99, 229-246.

Bird, J. E., \& Berman, L. S. (1985). Differing perceptions of mothers, fathers and children concerning children's academic performance. Journal of Psychology, 119, 113-124.

Butkowsky, I. S., \& Willows, D. M. (1980). Cognitive-motivational characteristics of children varying in reading ability: Evidence for learned helplessness in poor readers. Journal of Educational Psychology, 72, 408-482.

Campbell, J. R., \& Beaudry, J. S. (1998). Gender gap linked to differential socialization for high-achieving senior mathematics students. Journal of Educational Research, 91, 140-147.

Carr, M., Borkowski, J. G., \& Maxwell, S. E. (1991). Motivational components of underachievement. Developmental Psychology, 27, 108-118.

Chapman, J. W. (1988). Cognitive-motivational characteristics and academic achievement of learning disabled children: A longitudinal study. Journal of Educational Psychology, 80, 357-365.

Chapman, J. W., \& Tunmer, W. E. (1997). A longitudinal study of beginning reading achievement and reading self-concept. British Journal of Educational Psychology, 67, 279-291.

Cock, D., \& Halvari, H. (1999). Relations among achievement motives, autonomy, performance in mathematics, and satisfaction of pupils in elementary school. Psychological Reports, 84, 983-997.

De Corte, E. (1995). Fostering cognitive growth: A perspective from research on mathematics learning and instruction. Educational Psychologist, 30, 37-46.

Diener, C. I., \& Dweck, C. S. (1978). An analysis of learned helplessness: Continuous changes in performance, strategy, and achievement cognitions following failure. Journal of Personality and Social Psychology, 36, 451-462.

Dweck, C. S. (1986). Motivational processes affecting learning. American Psychologist, 41, 1040-1048.

Dweck, C. S. (1990). Self-theories and goals: Their roles in motivation, personality 
and development. In R. S. Dienstbier (Ed.), Nebraska Symposium on Motivation (Vol. 36, pp. 199-235). Lincoln, London: University of Nebraska Press.

Dweck, C. S., \& Leggett, E. L. (1988). A social-cognitive approach to motivation and personality. Psychological Review, 95, 256-273.

Entwisle, D. R., \& Alexander, K. L. (1990). Beginning school math competence: Majority and minority comparisons. Child Development, 61, 454-471.

Entwisle, D. R., \& Baker, D. P. (1983). Gender and young children's expectations for performance in arithmetic. Developmental Psychology, 19, 200-209.

Entwisle, D. R., \& Hayduk, L. A. (1978). Too great expectations: The academic outlook of young children. Baltimore: John Hopkins University Press.

Frome, P. M., \& Eccles, J. S. (1998). Parent' influence on children's achievementrelated perceptions. Journal of Personality and Social Psychology, 74, 435-452.

Galloway, D., Leo, E. L., Rogers, C., \& Armstrong, D. (1995). Motivational styles in English and Mathematics among children identified as having special educational needs. British Journal of Educational Psychology, 65, 477-487.

Galper, A., Wigfield, A., \& Seefeldt, C. (1997). Head Start parents' beliefs about their children's abilities, task values, and performance on different activities. Child Development, 68, 897-907.

Gerbing, D. W., \& Anderson, J. C. (1993). Monte Carlo evaluations of goodness-of-fit indexes for structural equation models. London: Sage.

Ginsburg, G. S., \& Bronstein, P. (1993). Family factors related to children's intrinsic/extrinsic motivational orientation and academic performance. Child Development, 64, 1461-1474.

Hess, R. D., Holloway, S. D., Dickson, W. P., \& Price, G. G. (1984). Maternal variables as predictors of children's school readiness and later achievement in vocabulary and mathematics in sixth grade. Child Development, 55, 19021912.

Huntsinger, C. S., Jose, P. E., Liaw, F. -R., \& Ching, W. -D. (1997). Cultural differences in early mathematics learning: A comparison of Euro-American, Chinese-American, and Taiwan-Chinese families. International Journal of Behavioral Development, 21, 371-388.

Jacobs, J. E. (1991). Influence of gender stereotypes on parent and child mathematics attitudes. Journal of Educational Psychology, 83, 518-527.

Jones, E. E., \& Berglas, S. (1978). Control of attributions about the self through selfhandicapping: The appeal of alcohol and the rate of underachievement. Personality and Social Psychology Bulletin, 4, 200-206.

Jöreskog, K., \& Sörbom, D. (1993). LISREL8: Structural equation modelling with the SIMPLIS command language. Hillsdale, N.J.: Lawrence Erlbaum Associates.

Lerkkanen, M. -K. (1998). The Mathematical Skill Test. Unpublished test material. Department of Teacher Education, University of Jyväskylä, Finland.

Liikanen, P. (1984). Lähtötilanteen kartoitus peruskoulun 1. luokalla. Kehityspsykologiset valmiudet koulumenestyksen ennustajana [Evaluation of the basic skills in the first grade: Cognitive skills as the predictors of school achievement]. (Report No. 23). Jyväskylä, Finland: University of Jyväskylä, Teacher Training college.

Ljungblad, T. (1971). Höstproven. Manual. [Höstproven test: A manual.]. Stockholm, Sweden: Skandinaviska Testförlaget. 
Louis, B., \& Lewis, M. (1992). Parental beliefs about giftedness in young children and their relation to actual ability level. Gifted Child Quarterly, 36, 27-31.

Lummis, M., \& Stevenson, H. W. (1990). Gender differences in beliefs and achievement: A cross-cultural study. Developmental Psychology, 26, 254-263.

Maccoby, E. E., \& Martin, J. A. (1983). Socialization in the context of the family: Parent-child interaction. In P. H. Mussen (Series Ed.) \& E. M. Hetherington (Vol. Ed.), Handbook of child psychology: Vol. 4. Socialization, personality, and social development (4 th ed., pp. 1-101). New York: Wiley.

Mantzicopoulos, P. (1990). Coping with school failure: Characteristics of students employing successful and unsuccessful coping strategies. Psychology in the Schools, 27, 138-143.

Marsh, H. -W., Walker, R., \& Debus, R. (1991). Subject-specific components of academic self-concept and self-efficacy. Contemporary Educational Psychology, 16, 331-345.

McCarney, S. B., \& Bauer, A. M. (1983-1991). Learning Disability Evaluation Scale (LDES). Columbia, MO: Hawthorne Educational Services.

Midgley, C., \& Urdan, T. C. (1995). Predictors of middle school students' use of self-handicapping strategies. Journal of Early Adolescence, 15, 389-411.

Miller, S. A. (1986). Parents' beliefs about their children's cognitive abilities. Developmental Psychology, 22, 276-284.

Miller, S. A. (1988). Parents' beliefs about children's cognitive development. Developmental Psychology, 59, 259-285.

Mujis, R. D. (1997). Symposium: Self-perception and performance. Predictors of academic achievement and academic self-concept: A longitudinal perspective. British Journal of Educational Psychology, 67, 263-277.

Murphey, D. A. (1992). Constructing the child: Relations between parents' beliefs and child outcomes. Developmental Review, 12, 199-232.

Musun-Miller, L., \& Blevins-Knabe, B. (1998). Adults' beliefs about children and mathematics: How important is it and how do children learn about it? Early Development and Parenting, 7, 191-202.

Newcomer, P. L., \& Curtis, D. (1984-1990). Diagnostic Achievement Battery, Second Edition (DAP-2). Austin, TX: PRO-ED.

Nicholls, J. G., Cheung, P. C., Lauer, J., \& Patashnick, M. (1990). Individual differences in academic motivation: Perceived ability, goals, beliefs, and values. Learning and Individual Differences, 1, 63-84.

Nolen-Hoeksema, S., Girgus, J. S., \& Seligman, M. E. P. (1992). Predictors and consequences of childhood depressive symptoms: A 5-year longitudinal study. Journal of Abnormal Psychology, 3, 405-422.

Nurmi, J. -E., \& Aunola, K. (2000). Unpublished raw data. University of Jyväskylä, Finland.

Nurmi, J.-E., Onatsu, T., \& Haavisto, T. (1995). Underachievers` cognitive and behavioural strategies - self-handicapping at school. Contemporary Educational Psychology, 20, 188-200.

Onatsu, T., \& Nurmi., J. -E. (1997). Unpublished raw data. University of Helsinki, Finland.

Onatsu-Arvilommi, T. P., \& Nurmi, J. -E. (2000). The Role of task-focused and task-avoidant behaviors in the development of reading and mathematical 
skills during the first school year: A cross-lagged longitudinal study. Journal of Educational Psychology, 92, 478-491.

Onatsu-Arvilommi, T. P., Nurmi, J. -E., \& Aunola, K. (1998). Mothers' and fathers' well-being, parenting styles, and their children's cognitive and behavioural strategies at primary school. European Journal of Psychology of Education, 13, 543-556.

Onatsu-Arvilommi, T., Nurmi, J.-E., \& Aunola, K. (2000). The development of achievement strategies and academic skills during the first year of primary school. Manuscript submitted for publication.

Okagaki, L., \& Frensch, P. A. (1998). Parenting and children's school achievement: A multiethnic perspective. American Educational Research Journal, 35, 123-144.

Pajares, F., \& Graham, L. (1999). Self-efficacy, motivation constructs, and mathematics performance of entering middle school students. Contemporary Educational Psychology, 24, 124-139.

Pajares, F., \& Kranzler, J. (1995). Self-efficacy beliefs and general mental ability in mathematical problem-solving. Contemporary Educational Psychology, 20, 426443.

Pajares, F., \& Miller, M. D. (1994). Role of self-efficacy and self-concept beliefs in mathematical problem solving: A path analysis. Journal of Educational Psychology, 86, 193-203.

Parsons (Eccles), J. E., Adler, T. F., \& Kaczala, C. M. (1982). Socialization of achievement attitudes and beliefs: Parental influences. Child Development, 53, 310-321.

Peet, S. H., Powell, D. R., \& O’Donnel, B. K. (1997). Mother-teacher congruence in perceptions of the child's competence and school engagement: Links to academic achievement. Journal of Applied Developmental Psychology, 18, 373393.

Phillips, D. A. (1987). Socialization of perceived academic competence among highly competent children. Child Development, 58, 1308-1320.

Phillips, D., \& Zimmerman, M. (1990). The developmental course of perceived competence and incompetence among competent children. In R. J. Sternberg \& J. Kolligian, Jr. (Eds.), Competence considered (pp. 41-66). New Haven: Yale University Press.

Pratt, M. W., Green, D., MacVicar, J., \& Bountrogianni, M. (1992). The mathematical parent: Parental scaffolding, parent style, and learning outcomes in long-division mathematical homework. Journal of Applied Developmental Psychology, 13, 17-34.

Rijavec, M., \& Brdar, I. (1997). Coping with school failure: Development of the school failure coping scale. European Journal of Psychology of Education, 12, 3749.

Salonen, P., Lepola, J., \& Niemi, P. (1998). The development of first graders' reading skill as a function of pre-school motivational orientation and phonemic awareness. European Journal of Psychology of Education, 2, 155-174.

Salonen, P., Lepola, J., Vauras, M., Rauhannummi, T., Lehtinen, E., \& Kinnunen, R. (1994). Diagnostiset testit 3: Motivaatio, metakognitio ja matematiikka. [Diagnostic Tests 3: Motivation, metacognition and mathematics.] Turku, Finland: University of Turku, The Center for Learning Research. 
Skaalvik, E. M. (1997). Self-enhancing and self-defeating ego orientation: Relations with task and avoidance orientation, achievement, self-perceptions, and anxiety. Journal of Educational Psychology, 89, 71-81.

Stevenson, H., \& Newman, R. (1986). Long-term prediction of achievement and attitudes in mathematics and reading. Child Development, 57, 646-659.

Wagner, B. M., \& Phillips, D. A. (1992). Beyond beliefs: Parent and child behaviors and children's perceived academic competence. Child Development, 63, 13801391.

Wigfield, A., \& Meece, J. L. (1988). Math anxiety in elementary and secondary school students. Journal of Educational Psychology, 80, 210-216.

Zuckerman, M., Kieffer, S. C., \& Knee, C. R. (1998). Consequences of selfhandicapping: Effects on coping, academic performance, and adjustment. Journal of Personality and Social Psychology, 74, 1619-1628. 